\title{
Conversion Experience of Akan Christian Royals in Ghana
}

\author{
Kwabena Opuni-Frimpong ${ }^{1}$ (D) \& Michael Kwadwo Ntiamoah ${ }^{1}$ \\ 1 Department of Religious Studies, Kwame Nkrumah University of Science and Technology, Kumasi-Ghana
}

\begin{abstract}
The study is an examination of the conversion challenges confronting Akan Christian Royals in Ghana. The Western missionaries and missionary established churches demand that as part of their conversion requirements, Akan Royals must reject and disassociate themselves from the Black Stool, ancestors and all ancestral related activities. The Royals who claim that their families have become Christian royal families insist that authority symbols like the Black Stools and ancestral ceremonies like the Adae do not take the place of the sovereignty of God and the Lordship of Christ in their belief system. Moreover, participation in Palace services prepares them for traditional leadership and does not take them away from their faith in Christ. The traditional leadership institutions and the Royals that welcomed the Western missionaries, provided them with hospitality, security and resources for the missionary work have come to be considered as unchristian and an anathema to the Christian faith. The position of the church has created tensions within Akan Christian Royal and put the genuineness of their conversion in doubt. The study which is qualitative in nature uses both primary and secondary methods in its information gathering. Its findings provide responses to some contemporary tensions in gospel and culture studies in African Christianity.
\end{abstract}

Keywords: Akan Royals, Christian Conversion, Cultural Identity, Black Stool, Authority Symbols

\author{
Correspondence \\ Kwabena Opuni-Frimpong \\ Email: opuni@hotmail.com \\ Publication History \\ Received 21st October, 2021 \\ Accepted 18th November, 2021 \\ Published online 26th November, \\ 2021
}

\section{INTRODUCTION}

The Western missionaries used Salem and Schools as Christian formation patterns for the nurturing of converts in Akan communities. ${ }^{1}$ The schools for instance that attracted people of all ages and backgrounds also attracted students from the Palace and Royals. The mission schools pursued comprehensive education that targets the head, the hand and the heart. ${ }^{2}$ Many of the students who achieved academic laurels in mission schools also ended up becoming converted into the Christian faith.

Akan Royals who have accepted the Christian faith like the others in schools and Salem do not have any doubt about the genuineness of their conversion and belief in the saving grace of God and Lordship of Christ. ${ }^{3}$ The genuineness of the conversion of Akan Royals has however, received consistent resistance from Western missionaries and missionary instituted churches due to their association with some traditional beliefs and practices. While the church expects the royals to completely abandon and disassociate themselves from the traditional leadership institution, the royals keep insisting that the concerns of the church do not actually take anything away from the genuineness of their Christian conversion.

\footnotetext{
Hans W. A Debrunner, History of Christianity in Ghana (Accra: Waterville Publishing House 1967).

Noel Smith, The Presbyterian Church of Ghana 1835-1960. (Accra: Ghana University Press, 1966).

Interview with Okyeame Ampratwum on June 1, 2004 at Asante Mampong in the Ashanti Region of Ghana. 
The claim of genuine conversion of the Akan Royals which the church considers to be in doubt, has however, been acknowledged and accepted by the traditional community and the Palace. The Royals and traditional leaders have come to be recognized as Christian Royals and chiefs. The families of Akan Royals who have accepted the Christian faith have subsequently been considered and recognized as Christian Royal families. According to the Omanhene of Asante Mampong Nana Osei Bonsu, 'the missionaries introduced Christianity in Asante and built schools to educate people, especially the members of the Royal family. People became Christians while in school and in the course of time most Royals were converted to the English Church Mission. We find that our families were Christians at birth; in other words, we were born into Christianized royal families. ${ }^{4}$

Some missionary churches have sustained the doubt of the genuineness of the conversion of the Christian Royals even in the post-missionary Akan churches. The Presbyterian Church of Ghana for instance insists that traditional functionaries can not become Christians. According to the Constitution of the church, 'no Christian is expected to be a stool/skin functionary, for almost every stool functionary has to participate in some ceremony connected with ancestral spirits and it is evident that no categorical declaration on the purely civil significance of the various stool emblems and ceremonies can be made. ${ }^{5}$

The study seeks to ascertain whether Akan Palace functions hinder the Akan Royals from the Sovereignty of God and the Lordship of Christ. Moreover, the study intends to appreciate the significance of the Black Stool and its related functions in the Palace and identify the dimensions that have been considered as conversion challenges to the conversion of the Akan Christian Royals.

\section{METHODOLOGY}

The study, been qualitative in nature adopted both primary and secondary sources in its information gathering. Available relevant materials on Akan Christian Royals in Asante, Akuapem and Akyem were examined to appreciate the conversion challenges of the Akan Royals. Selected individuals with insights into Akan Royals and the Christian faith were interviewed to appreciate the conversion challenges of Akan Christian Royals. The observation and interviews were done with the intention to appreciate the interface between the Akan traditional leadership institution and the Christian faith in order to establish the challenges that have existed between the Christian faith and the conversion of Akan Christian Royals.

\section{The Challenge of being a Christian and an Akan Royal}

The integration of the Christian faith and Akan traditional belief systems has remained a challenge in Christianity in Akan communities. ${ }^{6}$ The challenge has affected the spirituality and conversion of Akan Christian Royals. While the Akan Royals want to maintain their faith in Christ, they are equally aware of their royal responsibilities and are willing to make themselves available for traditional service to the communities.

The Akan indigenous belief systems and values shaped the spirituality and cultural identity of Akan Royals. $^{7}$ The Royals and Palace functionaries provided leadership to the communities even before the arrival of the Western missionaries. The indigenous belief values encouraged the Akan traditional leaders and the Palace functionaries to welcome the missionaries as they introduced the Christian faith to the Akan people. ${ }^{8}$ However, rejection and disassociation from the traditional belief systems and Palace functions were considered as requirements for Christian conversion. As part of the conversion requirements of Akan Royals, Williamson has observed that, 'the convert learned to avoid all kinds of traditional practices, and all too often to despise the old pattern of life.' 9

4 Irene Odotei, and George Hagan, The King Returns: Enstoolment of Asantehene Osei Tutu II. (Accra: Institute of African Studies, 2002), 133.

5 Presbyterian Church of Ghana, Constitution 2016 Edition (Accra: Waterville Publishing House).

6 Kwabena Opuni-Frimpong, "Jesus Shall Reign? An Examination of Christian Mission to the Akan Palace," Pentecostalism, Charismaticism and Neo-Prophetic Movements Journal 2, no.4 (2021): 29-41. https://doi.org/10.38159/pecanep.2021241

7 Kwadwo Ntiamoah, Religious and Social relevance of Nsuae (oath swearing) in Akan indigenous formation E-journal of Religious and Theological Studies, 1, no. 2. (September, 2015): 122- 139.

8 Kwabena Opuni-Frimpong, “Akan Indigenous Knowledge Systems and the Christian Faith in Ghana: A Review of the Major Works of Robert Rattray” E-Journal of Religious and Theological Studies, 7 no.8 (2021): 107-119 https://doi.org/10.38159/erats.2021781

9 Sidney G. Williamson. Akan Religion and the Christian Faith-A Comparative Study of the Impact of Two Religions. (Accra: Ghana University Press, 1965.), 57. 
The Christian conversion requirements of Akan Royals indicated that they must disassociate from the traditional leadership institution before their conversion to the Christian faith could be considered genuine and authenticated. The conversion requirements have been considered as an imposition of the cultural worldview of European value setting on the Akan cultural belief system. ${ }^{10}$ In his estimation, Williamson has pointed out that, 'the missionary attitude to indigenous beliefs and practices and to traditional institutions has left at least the impression that in the eyes of Western missionaries everything African is to be condemned.' 11

The concern of Akan Royals in their conversion process was how to maintain their newfound faith in Christianity and also maintain their cultural identity as Akan Royals as indicated by Kwame Bediako. ${ }^{12}$ For Busia, "the new convert is poised between two worlds: the old traditions and customs he is striving to leave behind, the new beliefs and practices to which he is still a stranger. The church would help him better, if she understood the former while she spoke with authority about the latter. ${ }^{13}$

The conversion challenges subsequently led to some level of lack of confidence in the conversion of Akan Christian Royals. In responding to the conversion challenges of Akan Christian Royals Busia has argued that, "for conversion to the Christian faith to be more than superficial, the Christian church must come to grips with traditional beliefs and practices, and with the worldview that these beliefs and practices imply.' ${ }^{14}$

Conversion was pursued through disassociation without engagements on the pre-conversion belief systems. The conversion requirements prescribed for the Akan Christian Royals have therefore been observed as inadequate to meet the spiritual needs of the Akan Christians. ${ }^{15}$ Williamson has opined that 'the issue of importance is, not whether the church has been established, but what kind of church and whether it is integrated with Akan society and able to meet in a real and vital fashion Akan spiritual need.' ${ }^{16}$ Conversion challenges and questions of the royals remained unanswered as the issues involved are not accommodated in the Christian education and nurturing programmes of the church.

The acceptance of the Christian faith by the Akan Royals does not mean the rejection of Akan indigenous belief values. The insistence of the church for the Royals to reject and disassociate from the indigenous belief values has however led to identity crisis and tension within Akan Royal converts. According to Noel Smith, 'the advent of Christianity and the adoption of the Christian faith by many Africans have not changed the traditional worldview, and it is this fact that has given rise to many of the problems which beset the Christian church today. ${ }^{17}$ The Royals in the church are struggling with an identity crisis as the church is not responding to their conversion challenges beyond the demand for disassociation and rejection.

The Black Stool, ancestors and ancestral related practices have remained the issues in the conversion challenges of Akan Christian Royals. On his reflection on the conversion challenges of the Akan Christianity Busia has observed that, 'for the Akan, the stool is the symbol par excellence of his future. This is why I threw the challenge, which I throw again that the question of the place of chieftaincy in the Christian church of the Gold Coast is important and urgent, if Christianity is to touch the whole of our group life. ${ }^{18}$ For Christianity to affect the entirety of Akan life the challenges of cultural integration must be adequately addressed. The gospel must engage cultural beliefs in the Black Stool that serve as the major authority symbol of the traditional leadership.

Williamson does not refute the immense contributions of the Basel Mission to Christian expansion in Ghana. ${ }^{19}$ His worry however, was the failure of missionaries to integrate the Christian faith into the cultural milieu of the Akan. His concern is that the church should be able to meet the real spiritual needs of the people

\footnotetext{
${ }^{10}$ Robert S. Rattray, Religion and Art in Ashanti. (London: Oxford University Press, 1927).

${ }^{11}$ Kofi A. Busia. 'Ancestor worship, libation, stools, festivals in S.G. Williamson (ed) Christianity and African Culture (Accra: Christian Council of Gold Coast, 1955), 158.

${ }^{12}$ Kwame Bediako, Theology and Identity: The Impact of Culture Upon Christian Thought in the Second Century and Modern Africa, (Oxford: Regnum Books 1992).

13 Sidney G. Williamson (ed) Christianity and African Culture (Accra: Christian Council of Gold Coast, 1955), iii.

${ }_{14}$ Williamson (ed). Christianity and African Culture, iii.

${ }^{15}$ Kwabena Opuni-Frimpong, K. "The Akan Traditional Leadership Formation: Some Lessons for Christian Leadership Formation" E-Journal of Humanities, Arts and Social Sciences 2, no.7 (2021): 75-91 https://doi.org/10.38159/ehass.2021272

16 Williamson. Akan Religion and the Christian Faith, 173.

17 Smith. The Presbyterian Church of Ghana 1835-1960, 65.

18 Busia. 'Ancestor worship, libation, stools, festivals in S.G. Williamson (ed) Christianity and African Culture, 22.

19 Kwabena Opuni-Frimpong "Christian Faith and Akan Culture in Ghana: A Review of Major Works of Sidney George Williamson" Journal of Mother-Tongue Biblical Hermeneutics and Theology 3, no.1(2021): 21-31. https://doi.org/10.38159/motbit.2021321
} 
and thus it must not present itself as an alien institution to the people. He therefore states that, 'the church is an alien institution, not yet rooted in Akan traditional life and failing to meet Akan spiritual need. ${ }^{20}$

\section{Akan Royals and Traditional Authority Symbols}

Akan indigenous leadership institution has served the leadership needs of both the Akan people as well as others who have associated with the Akan people. ${ }^{21}$ The indigenous leadership is closely knit to the Royal families. The Royal families are responsible for the identification, formation and maintenance of traditional leadership. The traditional authority symbols that serve as the symbols of office for traditional leaders are the preserve of the Royal families. ${ }^{22}$

The symbols of authority have been considered as marks of identity and ownership. They identify the families and the people who have the recognition to provide leadership to the communities. The Royals can claim access to leadership only when they are able to connect themselves to the authority symbols. The authority symbols are the recognition of the role of the ancestors who initiated the establishment of the communities. $^{23}$

Due to the fact that only the Royal families have the mandate to provide leadership in Akan communities, they are expected to make themselves available at all times for service. Rejection and disassociation from the traditional leadership and the authority symbols are considered as irresponsible behavior and betrayal by the Royals. They own the land that their ancestors have toiled for and therefore are expected to provide leadership for continuity. ${ }^{24}$

The beginnings of Akan communities were initiated by hunters and farmers who moved into communities to practice their trade. The hunters for instance after pilling up their game would go back to their original communities to solicit help from families and friends to assist in conveying the meat to the settlements. The people who accept to assist are provided with portions of land to build interim settlements while getting ready to travel. Such interim facilities are kept and later developed into bigger communities. The family of the original settler and their descendants remain the royals and providers of leadership to the communities. The word Odehyee which is explained to mean the owners of the boundaries is an indication that the original settler is the one who assigned the lands to the people and therefore is able to determine the specific areas that were allocated to the people. ${ }^{25}$

The descendants of the original settler who have access to leadership are traced from the female side of the family. The sons and daughters of the female royals are the Royals who have access to the throne. ${ }^{26}$ The Akan inheritance system is largely matrilineal. The assumption behind the matrilineal system, which prevails in the communities in which this study concentrated, is that mothers possess and therefore transmit royal blood. Men are considered to transmit not mogya (blood) but their sunsum (soul) and therefore do not share their blood with their children as women do. Identification and association with a person's maternal family therefore determine access to inheritance in the matrilineal communities. Such Royals inherit the properties of their uncles, mothers, brothers and that of their great-grandmothers and uncles. ${ }^{27}$

Akan royals are expected to maintain their Royal identity and cultural belief systems. They participate in Palace functions, traditional festivals, recognition of ancestors, Black Stools, libation prayers, traditional drumming and dancing. The participation in such traditional beliefs and activities has created tensions between Akan Christian Royals and the church. ${ }^{28}$ Some Royals have in the process distanced themselves from Palace beliefs and activities in order to maintain their Christian faith and positions. The church in some instances has also disciplined some Royals who have accepted traditional Royal functions by withdrawing them from the Holy Communion and denying them a full Christian burial. ${ }^{29}$

\footnotetext{
${ }^{20}$ Williamson. Akan Religion and the Christian Faith, 172-173.

${ }^{21}$ Opuni-Frimpong, "Akan Indigenous Knowledge Systems and the Christian Faith in Ghana.

22 Kwabena Opuni-Frimpong, "The Significance of the Black Stool as an Educational Resource in Akan Traditional Patterns of Learning," E-Journal of Religious and Theological Studies, 7 no.10 (2021): 153-165. https://doi.org/10.38159/erats.20217101

${ }^{23}$ Nana Addo Dankwa III, The Institution of Chieftaincy in Ghana - The Future. (Accra: Konrad Adenauer Foundation, 2004).

${ }^{24}$ Interview with Nana Addo Dankwa III November 22, 2004 Akropong Akuapem.

25 Opuni-Frimpong, "Jesus Shall Reign?

26 Interview with Addo-Fening June 6, 2004 Legon Accra.

27 Interview with Mercy Amba Oduyoye May14, 2004 Legon Accra.

${ }^{28}$ Interview with Sam Prempeh September 1, 2004 Osu Accra.

${ }^{29}$ Interview with Okyeame Ampratwum June 1, 2004 Asante Mampong.
} 
The Akan Christian royals insist that they do not deny nor replace the Lordship of Christ and the sovereignty of God with their ancestors. ${ }^{30}$ The Akan Royal Christians live in tension with the Christian faith in their conversion affirmation as some churches established by Western missionaries like the Presbyterian Church of Ghana reject their conversion without disassociation from the ancestors and traditional authority symbols like the Black Stool. ${ }^{31}$

\section{The Salem and Christian Conversion}

The creation of Salem communities remained a major formation and conversion pattern of the Basel Mission. Lands were acquired at the outskirt of the towns for Christian settlements. The assumption was that the new converts would not be able to maintain their newfound faith living in the traditional communities. The fear of being contaminated with 'heathen' cultural practices demanded that the Christians move out to new environments that were built with Christian values and belief practices. The Basel Mission used Biblical passages in support of their effort of separation. Williamson has noted that, 'the Basel Mission went farther, separating its converts geographically, grouping them in a segment of the town, called 'Salem', and using such scriptural injunctions as (2 Cor 6: 17). ${ }^{32}$

The Salem communities created another pattern of leadership in Akan communities. The traditional leaders and Palace functionaries were the sole community leaders before the arrival of the missionaries. The introduction of the Salem communities created another layer of community leadership in Akan communities as the Mission House and the church premises performed activities that previously were performed in the Palace and family houses. ${ }^{33}$ Church leaders assumed leadership in the communities in matters of dispute settlements, the performance of rites of passage like naming, marriage and funeral ceremonies. Confirmation of young people in the church and schools replaced the adolescent rites like dipo and bragoro as Christians were debarred from participation in such rites.

The Salems developed their own regulations, procedures and practices. Church members were required to live according to the Christian values and standards to qualify to attend the holy communion and Christian burial. Church members were further required to disassociate themself from traditional and cultural practices to guarantee their continuous stay in the Christian communities. Christians who accepted traditional face marks, Palace functions and sent their disputes to the Palace or family heads were subjected to Christian discipline including ex-communication and vacation from the Salem. Church members were prepared to stand against their traditional leaders on matters that the church leaders considered as unchristian and uncivilized. ${ }^{34}$

Akan Royals who accepted the Christian faith were equally asked to settle in the Salem. They were compelled like all church members to disassociate themselves from the traditional practices in order to maintain their continuous stay in the Salem. Several prominent traditional leaders objected to the creation of parallel leadership in the Akan communities but the Basel Mission did very little to respond to the accusation. Some of the converted royals that accepted to settle in the Salem were prepared to identify with the church and rejected their own family members. ${ }^{35}$

The gospel adopts the cultural categories of its cultural milieu for its interpretation and expression. ${ }^{36}$ The apostles and missionaries of the New Testament period seem to have approached their listeners on the basis of what they did believe, at least to the extent that they proclaimed Christ as the Saviour of men within a cultural milieu. ${ }^{37}$ The missionaries however, introduced European cultural worldview in their encounter with Akan people. According to Williamson 'the missionary enterprise among the Akan did not take this line, but being western in outlook and emphasis felt bound to deny the Akan worldview, not only on the basis of what was essentially Christian belief but on the ground of what was, in effect, a European worldview.' 38

\footnotetext{
${ }^{30}$ Interview with Okyeame Ampratwum June 1, 2004 Asante Mampong.

31 Presbyterian Church of Ghana Constitution 2016 Edition (Accra: Waterville Publishing House), 152.

32 Williamson. Akan Religion and the Christian Faith, 56.

33 Smith. The Presbyterian Church of Ghana 1835-1960.

34 Opuni-Frimpong. Christian Faith and Akan Culture in Ghana.

35 Opuni-Frimpong. Jesus Shall Reign?

36 Andrew Walls. The Missionary Movement in Christian History. (New York: Orbis Books, 1996).

37 Robert J. Schreiter. Constructing Local Theologies. (New York: Orbis Books, 1985).

38 Williamson. Akan Religion and the Christian Faith, 168.
} 
The Salem as a pattern of Christian formation and conversion is not very paramount in the postmissionary church in Akan communities. The conversion requirements of Akan Royal to disassociate themselves from ancestors and ancestral-related cultural practices have however, remained. There are instances where royals have declined Palace functions as a result of their Christian faith. Others have also come under church discipline for their decisions to accept Palace functions by the missionary instituted churches.

The conversion challenges of Akan Royals are related mainly to the Black Stool, ancestors and ancestral related activities. ${ }^{39}$ The missionary instituted churches insist that Christian conversion cannot be genuine unless the Royals and others reject and disassociate with the indigenous leadership/authority symbols. The Royals however, claim that the demands of the church on their conversion are a denial of service to the community that is a preserve of the Royals an action that makes them irresponsible to their various communities. The post missionary churches in Akan communities need to provide critical responses and answers to the conversion challenges confronting Akan Christian Royals. The responses must further pay attention to other functions of the Black Stool and ancestral related activities that Western missionaries used to determine the genuineness of the conversion experience of Akan Christian Royals.

\section{Akan Black Stool: Source of Oral Literature or Object for Propitiation?}

Responses to the tension between the Christian faith and Akan culture have remained an ongoing dialogue. The Christian Council of Ghana has made several efforts to provide responses to the conversion challenges of the Akan Christians. The 1955 meeting of the Christian Council of Ghana, for example, attempted to provide a response to the Christian Faith and the African culture tension. K. A. Busia who was one of the key presenters at the meeting pointed out that attention must be paid to the indigenous authority symbols like the Black Stools. According to him, Christianity can touch the whole of Akan life through the chieftaincy institution. ${ }^{40}$ The Black Stool subsequently has been considered as the major symbol that must be explored for its significant roles in the whole indigenous leadership system. ${ }^{41}$

Nana Addo Dankwa ${ }^{42}$ and Kwame Gyekye ${ }^{43}$ have pointed out that the Black Stool facilitates learning processes in Akan leadership formation. The significance of the authority symbol must therefore be appreciated according to its educational roles. Gyekye insists that the Black Stools are indigenous learning materials that facilitate education in theology, religion, history, governance and ethics. Akan traditional symbols are educational resources. Nana Addo Dankwa has further noted that, 'our forefathers, who at their time had not developed the art of writing and recording events, gave special significance to their culture and rituals by using such sculptural items as stools, dolls, etc. as symbols which were made to represent various important historical events. In effect, these special sculptural items became their books in which were embedded their early history, practices and experiences for posterity. ${ }^{44}$

The Black Stool is a learning material. According to Nana Addo Dankwa, the Black Stool 'is the literature that we have. ${ }^{45}$ In his attempt to trace the early beginnings of the creation of the Black Stool, he pointed out that the Black Stool was created to serve as material for documentation. He pointed out that, 'there was a time that we did not have a means of recording history and our ancestors used all sorts of things to represent historical events, the stools, the dolls and special stones. The long and short of the whole thing is that the basic means of educating our people are the symbols that we use and the major one is the Black Stool. ${ }^{46}$

The Akan Black Stool is considered by Busia ${ }^{47}$ and Nana Addo Dankwa ${ }^{48}$ as the most significant authority symbol for the Akan indigenous authority symbol. Addo Dankwa insists that, 'the Black Stool is the most important object in the Palace.' ${ }^{49}$ The importance of the Black Stool is more of its educational functions

\footnotetext{
39 Opuni-Frimpong "The Significance of the Black Stool as an Educational Resource in Akan Traditional Patterns of Learning”.

${ }^{40}$ Kofi A. Busia. The Position of the Chief in the Modern Political System of Ashanti, (Oxford: Oxford University Press, 1951 ), 28.

${ }^{41}$ Opuni-Frimpong "The Significance of the Black Stool as an Educational Resource in Akan Traditional Patterns of Learning,".

42 Nana Addo Dankwa. The Institution of Chieftaincy in Ghana - The Future.

43 Kwame Gyekye, African Cultural Values (Accra: Sankofa Publishing Company 1996).

${ }^{44}$ Nana Addo Dankwa. The Institution of Chieftaincy in Ghana - The Future, 72.

45 Interview with Nana Addo Dankwa Nov 22, 2004 Akuapem Akropong.

46 Interview with Nana Addo Dankwa Nov 22, 2004 Akuapim Akropong.

47 Busia Position of the Chief in the Modern Political System of Ashanti, 28.

48 Nana Addo Dankwa. The Institution of Chieftaincy in Ghana-The Future.

49 Nana Addo Dankwa. The Institution of Chieftaincy in Ghana - The Future, 67.
} 
than its sacred and religious roles. The church has considered the religious functions of the Black Stool and subsequently condemned and rejected all other significant roles. ${ }^{50}$

The Black Stool has been considered as an object for propitiation and favours. Akan traditional leaders therefore seek divine favours in the ceremonies that involve the Black Stool. Busia admits that during the Adae celebrations the people hope to receive favours and prosperity from their ancestors through their engagement with the Black Stool. He has noted that, 'Adae refers to those ceremonies at which the spirits of departed rulers of the clan are propitiated, their names and deeds recalled, and favours and mercy solicited.' ${ }^{51}$ He further argues that the Adae festival provides an opportunity for the people to receive prosperity and protection from their ancestors. Busia noted that, 'every twenty-one days an Ashanti ruler offers libations to his royal ancestors on behalf of his subjects, praying that the soil may be fruitful and the tribe of its increase. ${ }^{52}$

While Nana Addo Dankwa does not argue against the role of the Black Stool as an object for propitiation, he insists that the original and primary purpose is not prayer but education. Nana Addo Dankwa's belief system people do not become who they were not when they die. If you were not a chief death will not make you one. Moreover, if a person was not worshipped while alive Akan people do not worship them when such people die. Ancestors who were not worshiped while they were alive do not assume beings of worship when they die. The Black Stools that represent their memories cannot be objects of worship and replace the sovereignty of God. The Black Stool is indigenous learning material that facilitates teaching and learning during the Adae ceremony of traditional leaders and royals rather than being rejected due to its propitiation assumptions.

There are varied perspectives on the Black Stool. It is considered as both an object of propitiation as well as educational. An absolute condemnation creates an impression that the Black Stool does not have any Christian significance. An exploration into the Black Stool will present the helpful side of the traditional object and in the process, corrections done on the negative sides without total disassociation and condemnation. Even if the Black Stool plays propitiation roles in the Akan cultural belief system, the encounter with the Black Stool does not take the place of the sovereignty of God in the Akan religious thought.

\section{Ancestors and Adae Festival: A Learning Moment for Akan Royals or Worship Moment of the Ancestors?}

The Adae celebration has remained one of the major traditional celebrations on the Akan traditional calendar. The celebration brings together traditional leaders, Palace functionaries, Royal members of the communities and visitors. The celebration of the Adae has maintained both private and public activities. While the public activities are open to the larger society, the private activities are the preserve of the traditional leaders and the Royals. The Adae rituals which have remained in secrecy have remained under the rejection and condemnation of the church. An exploration into the Adae must be pursued to assist the conversation of the conversion challenges of Akan Royals.

The Adae is primarily educational in its nature and operations. ${ }^{53}$ The Akan associate wisdom and maturity with old age. Accumulated knowledge is related with elderly people. The ancestors are considered to be of maturity, wisdom and the desired knowledge that is needed by the society. The ancestors who are considered to be resting are part of the community. Akan society is made up of the dead, the living and the unborn. The accumulated wisdom of the ancestors can be sought after when their descendants get closer to them in their 'sleeping place' for engagement. The name Adae in the Akan language literally means sleeping place. The Adae celebration is built around the interest of the living communities to benefit from the accumulated wisdom of the elders. ${ }^{54}$

The primary intention of visiting the Black Stool room is educational and not spiritual. The Adae festival offers the opportunity to the traditional leaders to learn from the past, in the process they do offer prayers but the visitation of the Black Stool rooms is not primarily for the prayers. ${ }^{55}$ The Adae festival rituals involve offering drinks and food to the ancestors. The elements of the rituals remain symbolic. Nana Addo Dankwa has explained that, 'it is not true that the ancestors eat. It is not biologically correct. They are dead

\footnotetext{
50 Interview with Nana Addo Dankwa Nov 22, 2004 Akuapim Akropong.

${ }^{51}$ Busia. The Position of the Chief in the Modern Political System of Ashanti, 271.

52 Busia The Position of the Chief in the Modern Political System of Ashanti, 28.

53 Opuni-Frimpong, "Akan Indigenous Knowledge Systems and the Christian Faith in Ghana:

${ }^{54}$ Interview with Kwabena Nketia May 19, 2004 Madina Accra.

55 Interview with Nana Addo Dankwa, Nov 22, 2004 Akuapim Akropong.
} 
and gone but their memories should be preserved so that we would be able to learn about them when we go to the Black Stool room during the Adae period. ${ }^{56}$

Information about individual chiefs is represented by the Black Stools. The knowledge and memories that are embedded in the indigenous documentation symbols are retrieved when the royals and traditional leaders visit the sleeping place of the departed elders. There are Stool historians who share the memories behind each Black Stool during the Adae celebration. The consistency and frequency in sharing the stories protect the system from adulteration and distortion. Whenever you want to know about the secrets behind their success you go to them. Okyeame Ampratwum who has done the Black Stool room history education for 35 years said he always tries to avoid possible mistakes because if he does so, he will be reprimanded. ${ }^{57}$ The continuous celebrations of the Adae have contributed towards the preservation of Akan cherished memories and leadership values. The memories of the ancestors are preserved and celebrated so that those who want to emulate their examples will have access to the information and knowledge..$^{58}$

Akan traditional leadership formation involves the acquisition of knowledge in history, governance, diplomacy, legal system and spirituality. ${ }^{59}$ Education in such areas does require materials that will ensure the desired learning outcomes. By its nature, the indigenous symbol represents Akan identity, unity and continuity.$^{60}$ It is also the symbol of Akan traditional authority and power. The education of Akan traditional authority and power, unity, identity and continuity of the society is pursued through the constant interaction with the indigenous learning material by the Palace functionaries during the Adae ceremonies.

\section{Participation in Palace Functions: Leadership Formation Process or Exposure to Other Gods?}

Palace services have remained a major pattern in Akan leadership formation for the royals ${ }^{61}$ The perception from outside may suggest that the royals are exempted from services in the Palace. Service in the Palace is considered as a means of nurturing the Royals in the various functions in the Palace. The Royals perform the exact functions that other servants in the Palace are assigned to do. Some royals are deliberately sent to reside with certain knowledgeable traditional leaders to acquire the leadership trade. Such Royals perform the services that ordinary servants are tasked to perform without reference to their royalty. The Asantehene is on record of residing with the Omanhene of Sefwi Wiawso in his youthful period. The intention was to assist him to learn from the accumulated knowledge of the then Sefwi Omanhene.

The nurturing pattern expected that through participation, observation and engagements the royals will acquire the desired skills in the tasks and responsibilities of the Palace. Royals who distance themselves from the Palace functions are considered lazy and not fit for leadership. According to Okyeame Ampratwum, 'as the royals get involved in the various services in the Palace, they learn the desirable practices and values that are associated with Palace life. Service at the Palace is one of the major learning patterns in the traditional leadership formation.' ${ }^{62}$

According to Okyeame Ampratwum, 'some of these servants have accumulated knowledge due to their continuous service in the Palace. They acquire knowledge and experiences which have not been documented in books. Such knowledge can be exposed through observation and interaction during the moments of service. They further learn the value of humility and equality with all people. Their call to leadership is a call to higher service by leading the society in achieving the goals and values of the society. ${ }^{\prime}{ }^{6}$

Leadership is considered as service and it is demonstrated in the Palace. The Royals who aspire for traditional leadership are assessed by their participation in the Palace service. According to Okyeame Ampratwum, neglect of services in the Palace, 'is an indication that such Royals, if nominated for traditional leadership will not enjoy the cooperation of the ordinary servants who make a vital contribution to traditional governance in the Palace. ${ }^{94}$ Christian Royals participate in the Palace functions as part of their Royal formation responsibilities. Disassociation of the Royals from Palace services as insisted by the churches established by

\footnotetext{
56 Interview with Nana Addo Dankwa, Nov 22, 2004 Akuapim Akropong.

57 Interview with Okyeame Ampratwum. June 1, 2004 Asante Mampong.

58 Interview with Nana Addo Dankwa Nov 22, 2004 Akuapim Akropong.

59 Interview with Nana Addo Dankwa Nov 22, 2004 Akuapim Akropong.

${ }^{60}$ Interview with Okyeame Ampratwum. June 1, 2004 Asante Mampong.

${ }^{61}$ Opuni-Frimpong, The Akan Traditional Leadership Formation.

62 Interview with Okyeame Ampratwum. June 1, 2004 Asante Mampong.

${ }^{63}$ Interview with Okyeame Ampratwum. June 1, 2004 Asante Mampong.

${ }^{64}$ Interview with Okyeame Ampratwum. June 1, 2004 Asante Mampong.
} 
the Western missionaries, means neglect of leadership formation supposed to equip the Christian Royals for leadership.

\section{Some Lessons}

The examination of the conversion challenges confronting Akan Christian royals points out to lessons in ancestors and the Lordship of Christ, the Adae and the search for knowledge, Akan traditional leadership as service, Ohene Yesu in Akan Christian understanding and Akan Royals and Christian missions.

\section{Ancestors and the Lordship of Christ}

Akan religious thought system does not place ancestors in the positions of the sovereignty of God and the Lordship of Christ. In the Akan language, God is Onyankopon (the Almighty/Omnipotent One). He is considered as the Objades Nyame (the Creator God). He is Onyame (the one who satisfied One). The Akan do not ascribe any of the attributes of God to their ancestors. Akan people who are not even Christians do not consider their ancestors as occupying the same positions as the Supreme Being /God who must be worshiped. Akan Royal Christians do not have much difficulty in accepting the sovereignty of God and believing in the Lordship of Christ for their salvation and conversion.

Ancestors play very crucial roles in Akan community life. It must be noted however, that the Akan people do not assume positions that they were not while alive when they die. A person who was not a chief does not become a chief when they die. People who were not worshiped when they were alive do not become objects of worship when they die. Akan people do not worship their traditional leaders while alive and therefore do not worship them when they become their ancestors. Akan Royals provide service to their traditional leaders without worshiping them in any condition. The pattern does not change when the traditional leaders die. They are served without receiving the worship of the people when they die.

Some traditional leaders may direct their wishes to their ancestors but they remain ancestors without assuming the place of God. It must be noted that those who have not believed in the sovereignty of God and the Lordship of Christ may consider their ancestors as their objects of worship but that is the extreme position for such individuals. Akan people are even free to search for other deities for spiritual powers and prosperity. Such spiritual search can be done by both Christians and non-Christians without any serious connection with their identity as Royals. The Akan royals who have considered their sufficiency in the God that the Bible presents can equally hold on to their faith without any semblance of idolatry.

Akan Christians who have come to believe in the sovereignty of God ascribe worship and their prayers to the God who saves them through Jesus Christ. While Akan people who have not accepted Jesus Christ as their saviour may want to worship their ancestors and other deities, Akan royals who have come to the saving knowledge of God through Christ consider their ancestors 'a great cloud of witnesses' as Paul terms it 'we are surrounded by so great a crowd of witnesses' (Heb 12:1-2). Akan ancestors are only revered, they are not worshipped.

Joseph in the Book of Genesis instructed the Israelites to carry his bones with them as they journey back to the promised land (Gen 50:25). The maintenance of Joseph's bones was not intended to replace Joseph with Yahweh in the religious thought system of the people of God. The bones of Joseph were to keep reminding the people of God about the faithfulness of God and to keep them in faith with God. Akan people in their Christian formation must be helped to consider their ancestors as mentors and patterns of morality. They should not be denied conversion due to the recognition that they give to their ancestors.

The insistence of rejection and disassociation of ancestors before the conversion of Akan Royals can be considered as genuine in a theology done from the outside to the inside, ${ }^{65}$ the Western missionaries' value setting for non-Europeans ${ }^{66}$ and must be reconsidered. Theology of Akan ancestors must be done from the inside to the outside. Denying Akan Christians Royals genuine conversion is forcing the European already prepared all-size-fits-all garments for Akan Royal converts.

\section{The Adae and the Search for Knowledge}

The Akan is a learning community. The traditional patterns of learning prescribe specific learning patterns for specific age levels and professions. The Adae festival is primarily a unique leadership formation pattern for

\footnotetext{
${ }^{65}$ Opuni-Frimpong. Christian Faith and Akan Culture in Ghana.
}

${ }^{66}$ Kwame Bediako.Theology and Identity. 
the royals and traditional leaders. The Akan mentoring may allow royals to be sent to some knowledgeable individuals outside their jurisdictions to acquire desirable knowledge. The Akan nevertheless, pay much attention to their own accumulated knowledge that is built around their ancestors. Paul acknowledged Timothy for possessing the genuine faith that existed in his grandmother Lois, his mother Eunice and in himself (2 Tim 1:5). The Adae ceremony insists that while the Akan Royals may learn from other people, they must pay attention to the unique life experiences and information of their ancestors. Denying Akan Royals participation in the Adae ceremony is to build Akan society that is ignorant about their own history and stories, an action that Akan people can not simply accommodate.

\section{Akan Traditional Leadership as Service}

Leadership in Akan traditional leadership institution is service. The Akan adage is 'se Odehyee anko a, akoa $d$ wane' (if the royal decides not to fight/serve then the slaves are free to run away). The royals and the traditional leaders are expected to provide leadership of service. The royals however, learn servant leadership as they participate in the Palace functions. Participation in Palace functions is the leadership formation pattern of indigenous people. Christian leadership equally is a call to service. Jesus told his disciples that he was among them as one who serves (Lk. 22:27).

Akan traditional leadership is the preserve of the royals. They are expected to lead their societies through service. Akan Royals who distance themselves from service in the community are considered irresponsible, lazy and not fit for leadership. The conversion condition to Akan royals to distance themselves from the Palace functions is to create a leadership vacuum in Akan societies, a very serious societal challenge that Western missionaries did not attach much importance to. Some Royal gates have lost the opportunity to provide leadership to their people because the church insisted that they move to the Salem and disassociate themselves from their traditional leadership roles.

\section{Ohene Yesu in Akan Christian Understanding}

The Akan Royals are a unique group that provides traditional leadership to the Akan communities. The demand for rejection and disassociation if accepted by the royal families, is a move towards total extinction and destruction of the indigenous leadership system. The Palace and the identity of the chief have however made significant contributions to Christian understanding, expression and interpretation. Titles that are ascribed to traditional leaders have contributed to the Akan understanding of Christ.

The one in whom all the unique titles to the chief can be associated with is Jesus. The appellation for Ohene like Otumfuo (the Mighty One), Osahene (the Commander of the Army), Oseadeayo (the Faithful One) Okogyeaman (Deliverer of Nations), Osagyefo (Liberator) are appellations that Akan Christians understand, that must be used to praise the name of Ohene Yesu. Akan Christian understanding of Christ will be stronger if Akan Christology is deeply rooted in the traditional leadership and the royals instead of rejecting and condemning the traditional institution and the royals who are expected to provide traditional leadership. ${ }^{67}$

\section{Akan Royal Homes and Christian Missions}

Akan royals and traditional leadership institutions have made a significant contribution to Akan Christian growth despite the condemnation and rejection of the indigenous leadership institution by Western missionaries and missionary instituted churches. The traditional leadership according to Nana Addo Dankwa, actually 'accommodated and created an environment for the survival of the new entries of merchants and missionaries.' ${ }^{68}$

The very indigenous leadership institution that welcomed, sustained and provided resources for Christian mission at its early stages is considered to be an anathema of Christian conversion. If God is truly against the Akan royals and traditional leadership institution, he might have led the Western missionaries to other homes for survival and not the Palace. The very homes that welcomed the gospel cannot be denied the saving grace of God. The task of the post-missionary churches in Akan communities must consider the indigenous leadership institution that God used to welcome the missionaries and the gospel into Akan homes

\footnotetext{
${ }^{67}$ Pashington Obeng. Catholicism: Religious and Cultural Reproduction Among the Akan of Ghana. (New York: E.J. Brill 1996), 190.

68 Nana Addo Dankwa III, The Institution of Chieftaincy in Ghana - The Future.
} 
and societies and provide Christian missions and ministry to the Palace. The Akan Christian royal families must be supported to evangelize to members of the royal families to bring them into the knowledge of the saving grace of Christi rather than rejecting them and demanding that they disassociate themselves from their unique leadership opportunities.

\section{CONCLUSION}

As part of their conversion requirements, Akan Christian Royals have been demanded by the Western missionaries and missionary instituted churches to reject and disassociate themselves from the traditional leadership institutions. The church over the years has considered ancestors and ancestral related activities as being in tension with the Christian faith. The understanding of the traditional leadership practices was considered not as a result of engagement with the indigenous worldview of the cultural milieu but the European value setting for the Akan people. Even though the Royals have claimed on several occasions that ancestors and ancestral related activities do not take the place of the sovereignty of God and the Lordship of Christ, the genuineness of the conversion of the Royals has remained in doubt. The study has pointed out that a critical reflection on other dimensions of the Black Stools, Adae ceremonies, ancestors and Palace functions will respond to the conversion challenges of the Akan Christian Royals.

\section{ABOUT AUTHORS}

Kwabena Opuni-Frimpong ( $\mathrm{PhD}$ ), Lecturer in African Christianity, Department of Religious Studies, Kwame Nkrumah University of Science and Technology, Kumasi - Ghana.

Michael Kwadwo Ntiamoah, (MPhil). (PhD. Cand.). Lecturer at the Department of Religious Studies, Faculty of Social Sciences, Kwame Nkrumah University of Science and Technology, Kumasi. Ghana. He has research interests in Religious diversity in Ghana, Chieftaincy and African culture, Akan Indigenous Religion and Environment, Akan Indigenous Religion and Social Order.

\section{BIBLIOGRAPHY}

Bediako, Kwame. Theology and Identity: The Impact of Culture Upon Christian Thought in the Second Century and Modern Africa., Oxford: Regnum Books 1992.

Busia, K.A. The position of the chief in the modern political system of Ashanti, Oxford University Press, 1951.

Debrunner, Hans W. A History of Christianity in Ghana Accra: Waterville Publishing House 1967.

Gyekye, Kwame. African Cultural Values. Accra: Sankofa Publishing Company 1996.

Nana Addo Dankwa III, The Institution of Chieftaincy in Ghana - The Future. Accra: Konrad Adenauer Foundation, 2004.

Ntiamoah, Kwadwo. Religious and Social relevance of Nsuae (oath swearing) in Akan indigenous formation E-Journal of Religious and Theological Studies, Vol. 1, No. 2. (September, 2015): 122- 139.

Odotei, Irene and Hagan George, The King Returns: Enstoolment of Asantehene Osei Tutu II. Accra: Institute of African Studies, 2002.

Obeng, Pashington. Catholicism: Religious and Cultural Reproduction Among the Akan of Ghana. New York: E.J. Brill 1996.

Opuni-Frimpong, K. "Jesus Shall Reign? An Examination of Christian Mission to the Akan Palace," Pentecostalism, Charismaticism and Neo-Prophetic Movements Journal 2, no.4 (2021): 29-41. https://doi.org/10.38159/pecanep.2021241.

Opuni-Frimpong K. "The Significance of the Black Stool as an Educational Resource in Akan Traditional Patterns of Learning," E-Journal of Religious and Theological Studies, 7 no.10 (2021): 153-165. https://doi.org/10.38159/erats.20217101.

Opuni-Frimpong K. "Christian Faith and Akan Culture in Ghana: A Review of Major Works of Sidney George Williamson" Journal of Mother-Tongue Biblical Hermeneutics and Theology 3, no.1(2021): 21-31. https://doi.org/10.38159/motbit.2021321. 
Opuni-Frimpong, K. "Akan Indigenous Knowledge Systems and the Christian Faith in Ghana: A Review of the Major Works of Robert Rattray" E-Journal of Religious and Theological Studies, 7 no.8 (2021): 107-119 https://doi.org/10.38159/erats.2021781.

Opuni-Frimpong, K. "The Akan Traditional Leadership Formation: Some Lessons for Christian Leadership Formation" E-Journal of Humanities, Arts and Social Sciences 2, no.7 (2021): 75-91 https://doi.org/10.38159/ehass.2021272.

Presbyterian Church of Ghana, Constitution 2016 Edition (Accra: Waterville Publishing House)

Rattray, R. S. Ashanti. London: Oxford University Press 1955.

. Religion and Art in Ashanti. London: Oxford University Press, 1927. . Ashanti Law and Constitution. London: Oxford University Press 1916.

Schreiter, Robert J. Constructing Local Theologies. New York: Orbis Books, 1985.

Smith, Noel. The Presbyterian Church of Ghana 1835-1960. Accra: Ghana University Press, 1966.

Walls, Andrew. The Missionary Movement in Christian History. New York: Orbis Books, 1996.

Williamson, S.G. Akan Religion and the Christian Faith, Accra: Ghana University Press, 1965. .Christianity and African Culture. Accra: Christian Council of Gold Coast, 1955.

\section{APPENDIX}

Interview with Mercy Amba Oduyoye May14, 2004 Legon Accra.

Interview with Emily Akuffo May 14, 2004 Akropong Akuapem.

Interview with Kwabena Nketia May 19, 2004 Madina Accra.

Interview with Okyeame Ampratwum June 1, 2004 Asante Mampong.

Interview with Nana Owusu Afriyie June 2, 2004 Asante Mampong.

Interview with Sam Prempeh September 1, 2004 Osu Accra.

Interview with Addo-Fening June 6, 2004 Legon Accra.

Interview with Nana Addo Dankwa III November 22, 2004 Akropong Akuapem. 